\title{
SLC1A5 wt Allele
}

National Cancer Institute

\section{Source}

National Cancer Institute. SLC1A5 wt Allele. NCI Thesaurus. Code C118926.

Human SLC1A5 wild-type allele is located in the vicinity of 19q13.3 and is approximately $14 \mathrm{~kb}$ in length. This allele, which encodes neutral amino acid transporter $\mathrm{B}(0)$ protein, plays a role in both the transport of neutral amino acids and binding to select retroviruses. 